\title{
Teaching Video NeuroImages: Tardive diaphragmatic tremor
}

Harsh V. Gupta, MD

Neurology ${ }^{\circledR}$ 2020;94:e656. doi:10.1212/WNL.0000000000008761

A 75-year-old woman was prescribed pimozide $2 \mathrm{mg}$ twice a day 4 years previously for paranoid behavior. The patient developed involuntary movements in her abdomen following abrupt discontinuation of pimozide.

The movement was brief, involuntary, nonsuppressible, and jerk-like, associated with an audible sniff (video 1). These movements did not affect the patient's respiration and disappeared while she was eating or sleeping. The diagnosis of tardive diaphragmatic tremor was made, and the patient was started back on pimozide $2 \mathrm{mg}$ twice a day. A very low dose of clonazepam was added and pimozide was gradually discontinued. At the time of the follow-up visit, the movements had disappeared (video 2).

Diaphragmatic movements as a part of withdrawal dyskinesia have been described. ${ }^{1}$ In cases where this movement is seen in isolation without respiratory compromise, the term diaphragmatic tremor is preferred. ${ }^{2}$

\section{Study funding}

No targeted funding reported.

\section{Disclosure}

H.V. Gupta reports no disclosures relevant to the manuscript. Go to Neurology.org/N for full disclosures.

\section{References}

1. Burn DJ, Coulthard A, Connolly S, et al. Tardive diaphragmatic flutter. Mov Disord 1998;13:190-192.

2. Espay AJ, Fox SH, Marras C, et al. Isolated diaphragmatic tremor: is there a spectrum in "respiratory myoclonus"? Neurology 2007;69: 689-692.

\section{Correspondence}

Dr. Gupta

dr.harshgupta@gmail.com

\section{MORE ONLINE}

$\rightarrow$ Teaching slides

links.lww.com/WNL/

B26

- Videos 


\section{Neurology}

\section{Teaching Video NeuroImages: Tardive diaphragmatic tremor Harsh V. Gupta \\ Neurology 2020;94;e656 Published Online before print January 30, 2020 \\ DOI 10.1212/WNL.0000000000008761}

This information is current as of January 30, 2020

Updated Information \& Services

References

Subspecialty Collections

Permissions \& Licensing

Reprints including high resolution figures, can be found at: http://n.neurology.org/content/94/6/e656.full

This article cites 2 articles, 1 of which you can access for free at: http://n.neurology.org/content/94/6/e656.full\#ref-list-1

This article, along with others on similar topics, appears in the following collection(s):

All Movement Disorders

http://n.neurology.org/cgi/collection/all_movement_disorders Myoclonus

http://n.neurology.org/cgi/collection/myoclonus

Information about reproducing this article in parts (figures,tables) or in its entirety can be found online at:

http://www.neurology.org/about/about_the_journal\#permissions

Information about ordering reprints can be found online:

http://n.neurology.org/subscribers/advertise

Neurology ${ }^{\circledR}$ is the official journal of the American Academy of Neurology. Published continuously since 1951, it is now a weekly with 48 issues per year. Copyright (O) 2020 American Academy of Neurology. All rights reserved. Print ISSN: 0028-3878. Online ISSN: 1526-632X.

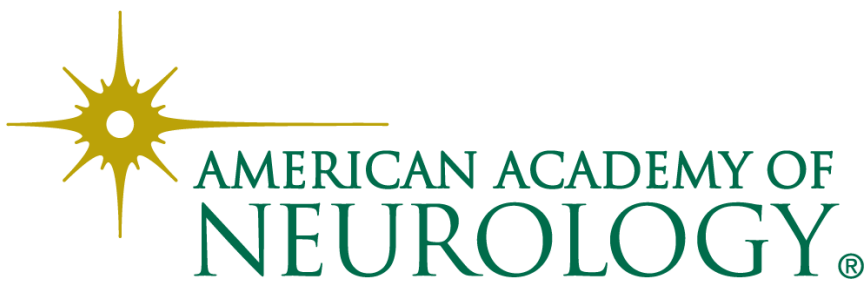

